\title{
MEASURED AND COMPUTED TEMPERATURE DISTRIBUTIONS IN THE LAW DOME ICE CAP, ANTARCTICA
}

\author{
By W. F. Budd, N. W. Young and C. R. Austin \\ (Antarctic Division, Department of Science, 568 St Kilda Road, Melbourne, Victoria 3004, \\ Australia)
}

Abstract. By 1969 considerable data had been collected over Law Dome from surface measurements. These included surface elevation, ice thickness, accumulation rates, ice movement and strain-rates, surface mean temperatures, and several temperature-depth gradients. Since then core drilling up to $380 \mathrm{~m}$ in depth has been carried out from the summit to the coast where the cores reached close to the bed. The bore holes have been concentrated on two main flow lines: one to Cape Folger and the other to Cape Poinsett. The bore-hole temperatures give a clear indication of the temperature distribution throughout the ice cap.

Numerical modelling shows that the measured deep temperatures closely match the steady-state temperature distribution calculated from the present regime. The variations in the temperature profiles over the dome are primarily associated with the flow regime.

The Cape Folger line has low accumulation rates and low velocities which results in positive surface temperature-depth gradients increasing towards the coast. By contrast the Cape Poinsett line has high accumulation rates and high velocities which result in a large negative temperature-depth gradient there. The profile at the Dome summit is close to isothermal primarily due to the high accumulation rates and lack of horizontal motion.

RÉsumé. Mesures et calculs des distributions des températures dans la calotte glaciaire de Law Dome. Des mesures de surface réalisées en 1969 , ont permis de recueillir un ensemble considérable de données sur le Law Dome. Ces données comprennent l'altitude de la surface, l'épaisseur de la glace, les taux d'accumulation, les vitesses de déformation du mouvement de la glace, les températures moyennes à la surface et plusieurs gradients de températures en profondeur. Depuis lors, des forages jusqu'à $380 \mathrm{~m}$ de profondeur ont été exécutés, depuis le sommet jusqu'à la côte où les forages ont atteind le lit rocheux. Les forages ont été concentrés sur deux principales lignes d'écoulement, l'une vers le Cap Folger et l'autre vers le Cap Poinsett. Les températures dans le forage donnent une claire indication de la distribution de la température à travers la calotte.

La modélisation numérique montre que les températures en profondeur suivent exactement la distribution des températures à l'état d'équilibre, calculée à partir du régime actuel. Les variations dans les profils de température dans le passé sont d'abord liées au régime d'écoulement.

La ligne d'écoulement du Cap Folger a de faibles taux d'accumulation et de faibles vitesses qui aboutissent à des gradients verticaux positifs des températures de surface qui croissent en allant vers la côte. Au contraire, la ligne du Cap Poinsett a un fort taux d'accumulation et des vitesses rapides qui donnent en ces points un gradient vertical de température largement négatif. Le profil au sommet du Dome est sensiblement isotherme, surtout en raison du haut niveau de l'accumulation et de l'absence de mouvement horizontal.

Zusammenfassung. Gemessene und berechnete Temperaturverteilungen in der Eiskalotte des Law Domes. Bis zum Jahre 1969 war eine stattliche Menge von Daten über den Law Dome aus Oberflächenmessungen angesammelt worden. Im einzelnen erstreckten sie sich auf die Höhe der Oberfläche, die Eisdicke, die Akkumulationsraten, die Eisbewegung und -deformation, die mittlere Oberflächentemperatur und einige Temperaturgradienten im Inneren. Seitdem wurden Kernbohrungen bis $380 \mathrm{~m}$ Tiefe vorgenommen, und zwar vom Scheitel bis zur Küste, wo die Bohrkerne fast den Untergrund erreichen. Die Bohrungen konzentrierten sich auf zwei Hauptstromlinien: eine zum Cape Folger, die andere zum Cape Poinsett. Die Temperaturen in den Bohrlöchern vermitteln eine klare Vorstellung von der Temperaturverteilung in der Eiskalotte.

Modellrechnungen zeigen, dass die in der Tiefe gemessenen Temperaturen gut mit jener stationären Temperaturverteilung übereinstimmen, die sich aus dem derzeitigen Zustand rechnerisch herleiten lässt. Die Unterschiede zwischen den Temperaturprofilen auf dem Dom lassen einen wesentlichen Zusammenhang mit den Fliessverhältnissen erkennen.

Die Linie zum Cape Folger weist niedrige Akkumulationsraten und niedrige Geschwindigkeiten auf, was zu positiven Temperaturgradienten von der Oberfläche zur Tiefe führt, die gegen die Küste hin noch zunehmen. Im Gegensatz dazu sind die Akkumulationsraten und Geschwindigkeiten auf der Cape PoinsettLinie hoch; dies hat einen grossen negativen Temperaturgradienten mit der Tiefe zur Folge. Das Profil über den Scheitel des Domes ist nahezu isotherm, vor allem infolge der hohen Akkumulationsraten und wegen des Fehlens einer horizontalen Bewegung.

\section{INTRODUCTION}

The Law Dome, previously referred to as the Wilkes local ice cap by Budd (1968, r969, I 970) is about $200 \mathrm{~km}$ diameter and reaches I $390 \mathrm{~m}$ elevation at its summit. The ice cap overlays an irregular bedrock rise which averages about $300 \mathrm{~m}$ elevation near the centre 
where the ice thickness is about $\mathrm{I}$ I $00 \mathrm{~m}$. To the north the ice cap runs into the ocean where the bedrock is about $200-400 \mathrm{~m}$ below sea-level. To the south the ice flows into a deep bedrock depression joining the Totten and Vanderford Glaciers, and there it merges with the main East Antarctic ice sheet at the bottom of the surface valley (cf. Fig. I). The Law Dome thus represents an ideal medium-scale ice cap which is conveniently situated near Casey (lat. $66^{\circ} 16.7^{\prime}$ S., long. $110^{\circ} 32.1^{\prime}$ E.), about $2 \mathrm{~km}$ south of the former station Wilkes.

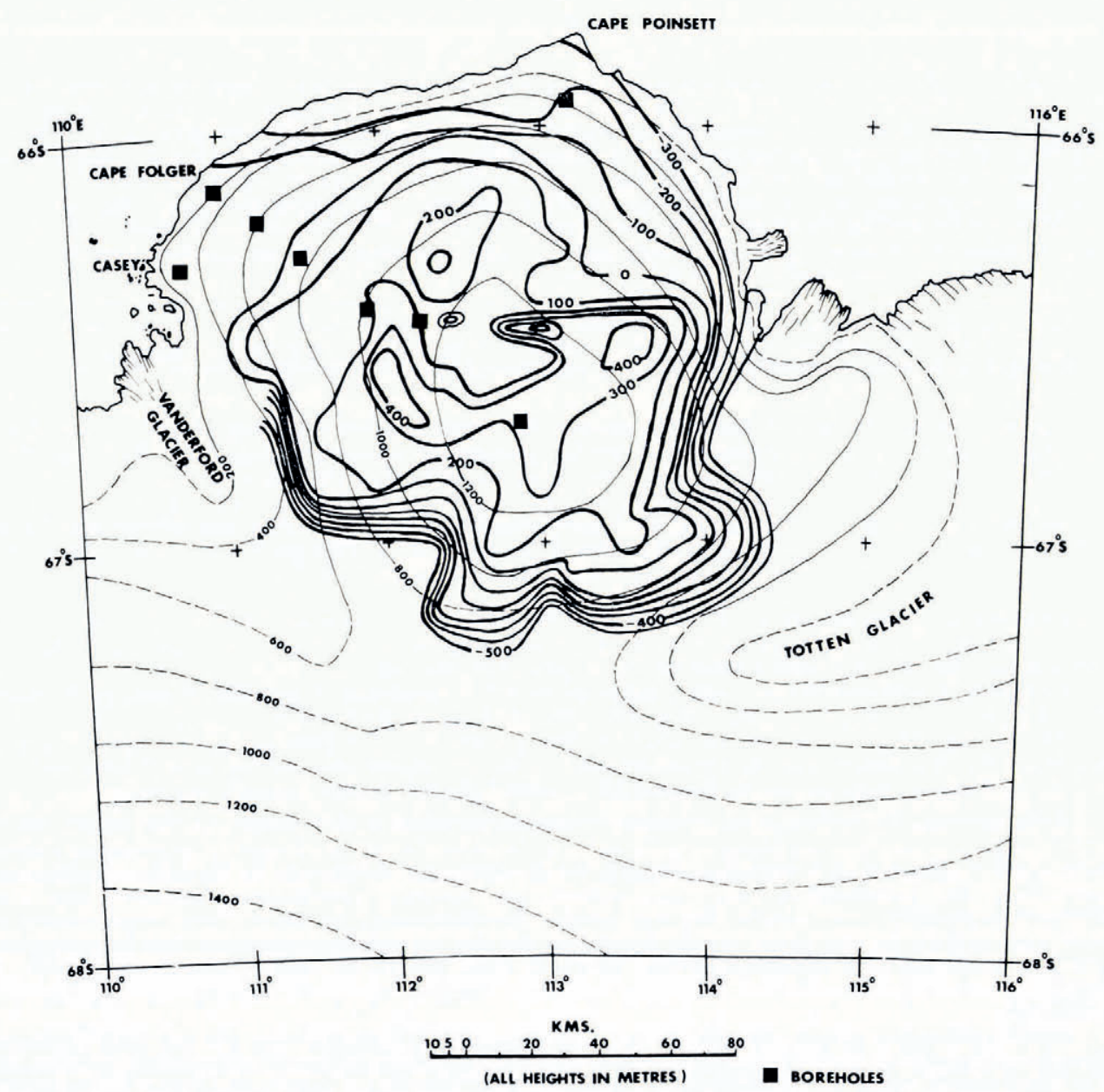

Fig. I. Law Dome surface and bedrock elevations are shown with the locations of the bore-hole sites.

Following the initial work of the United States glaciologists, Cameron and others (I959) and Hollin and others (196I), the Australian National Antarctic Research Expedition (ANARE) glaciology programs have concentrated on collecting data over the Law Dome and south to the East Antarctic ice sheet towards Vostok. Much of this earlier work has been reported by Budd ( 1966 , I969). A summary of the glaciological work to that date is given by Budd (1970) and of the geophysics by Allen and Whitworth (1970).

Since then the $16 \mathrm{~km}$ grid network over the ice cap for elevation and ice thickness has been completed by L. Denham in 1970 using radio-echo profiling and continuous barometric 
levelling. This has now provided a relatively sound basic set of data over the ice cap for surface and bedrock elevation, ice thickness, and accumulation rate (cf. Figs I and 2).

Surface velocities and strain-rates have been measured from the centre to the coast around a large northern triangle and a smaller triangle to the south. The results of these measurements are illustrated in Figure 2.

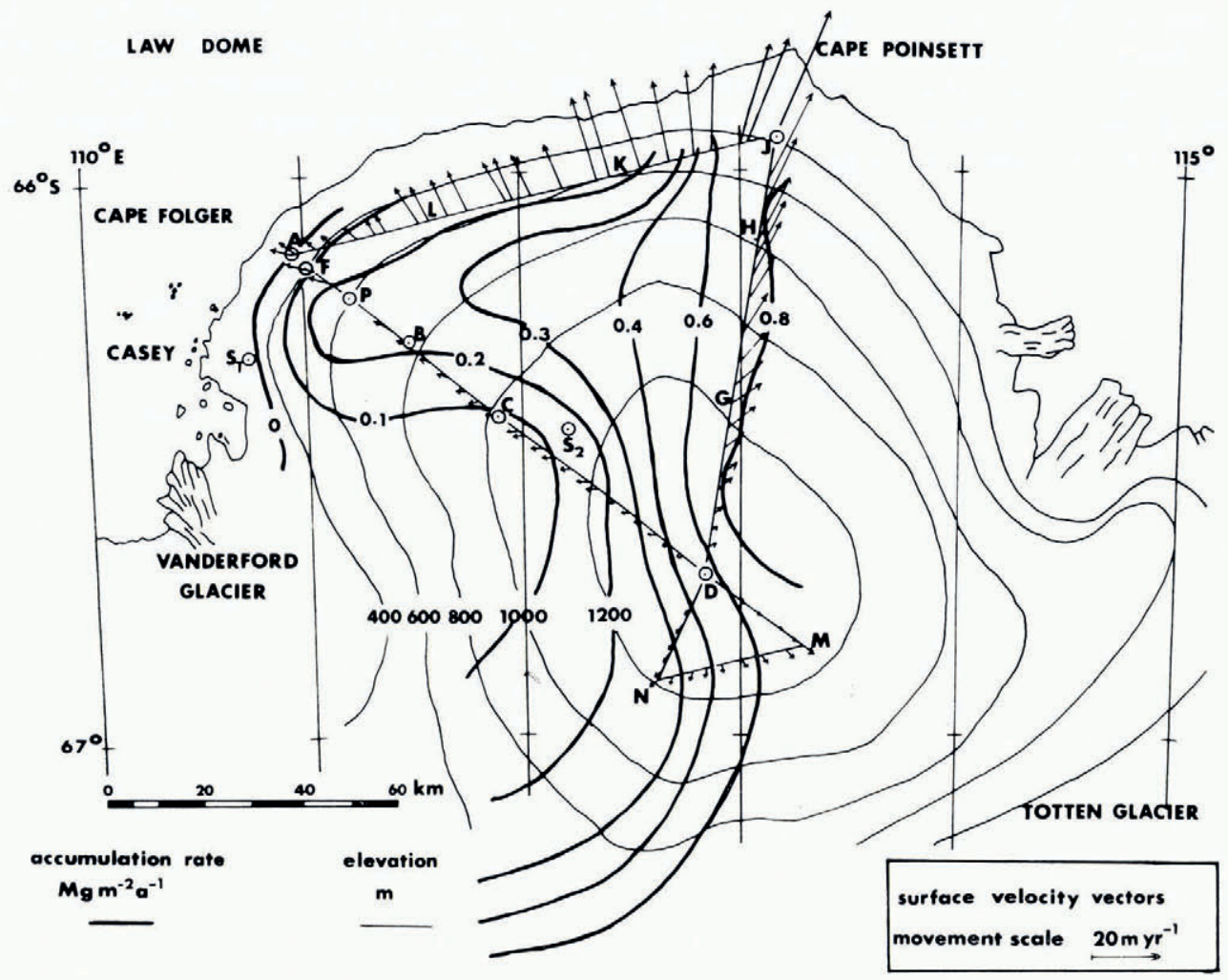

Fig. 2. Measured net accumulation rates and velocities over Law Dome show a gradient of greatly increased flux from west to east.

\section{Surface mean temperatures}

Temperatures to the depth of $10 \mathrm{~m}$ in the firn have been measured at many locations over the ice cap. In general the data above $400 \mathrm{~m}$ confirm the pattern of variation of mean surface temperature with elevation of approximately $\mathrm{I} \mathrm{deg} / \mathrm{I}$ oo $\mathrm{m}$ reported by Cameron (I964). Below $400 \mathrm{~m}$ Cameron indicated that the $\mathrm{s} \mathrm{m}$ temperatures were up to several degrees warmer than indicated by the above linear relation. Detailed measurements of temperature at eight levels to $16 \mathrm{~m}$ reported by Cameron and Bull (I962) showed that the io $\mathrm{m}$ temperature at a site $262 \mathrm{~m}$ in elevation over a period of two years had a mean $3 \mathrm{deg}$ warmer than the surface. This phenomenon has been observed primarily in regions of ablation where the ice has a clear "blue ice" appearance. Budd (1967) showed that the differential absorption of solar radiation with depth in blue ice could account for the measured variation in mean annual temperature with depth and the resultant higher $10 \mathrm{~m}$ temperatures relative to the surface. 
The line from the Dome summit to Cape Folger, some $20 \mathrm{~km}$ to the north-east of Casey seems to reach the ablation zone on the average just beyond the first bore hole at strain grid $\mathrm{A}$ of the northern triangle corner where the elevation is $280 \mathrm{~m}$. As a result the measured ro $\mathrm{m}$ temperatures along this line conform closely to the I deg/ Ioo $\mathrm{m}$ relation.

A certain amount of variability can be expected in $10 \mathrm{~m}$ temperatures due to longer-term variations in mean surface temperatures. For example the record of annual mean temperatures for Wilkes-Casey are shown in Figure 3. The similarity of these temperatures with those of Mirny and Dumont d'Urville shown by Budd (1975) suggests that they reflect real, largescale, changes of amplitude of about $\mathrm{I}$ deg over a time period of many years. This kind of surface-temperature variation could give rise to variations of amplitude several tenths of a degree at the ro $\mathrm{m}$ level from one year to another. Below $20 \mathrm{~m}$ only much longer-term changes are expected to be apparent.

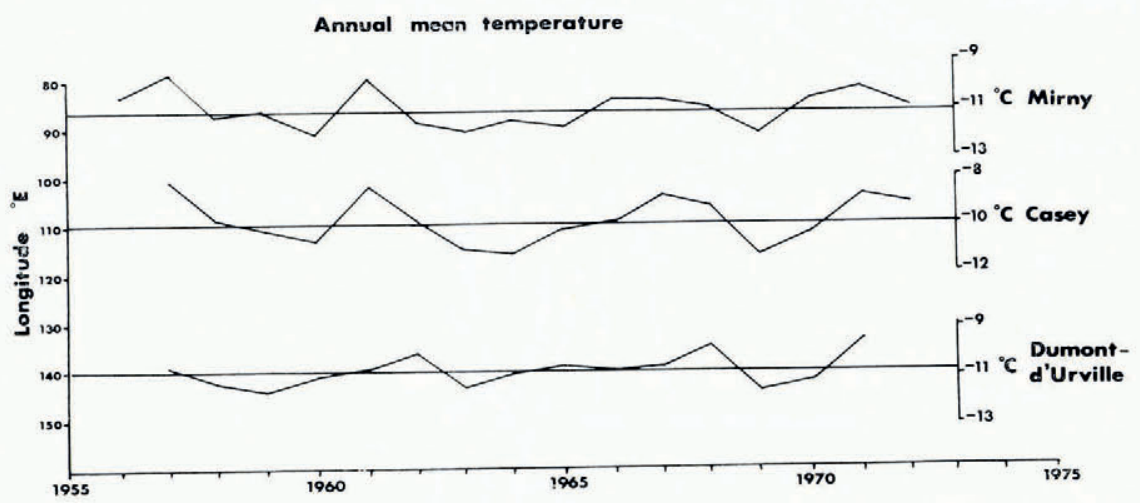

Fig. 3. The record of annual mean temperatures from Wilkes and Casey are shown together with those of the neighbouring stations Mirny and Dumont d'Urville (from Budd, 1975).

\section{Temperature-Depth gradients}

A number of temperature-depth gradients below $20 \mathrm{~m}$ from the coast to the interior of Law Dome were measured in 1961 by Budd (cf. Budd ig66). In 1962 A. Battye continued with further gradients to over $60 \mathrm{~m}$ depth on Law Dome and extended them inland towards Vostok. These temperature gradients were generally clear linear trends of temperature below $20 \mathrm{~m}$ and on Law Dome showed a smooth trend of decrease in gradient from about $3 \mathrm{deg} /$ I $00 \mathrm{~m}$ near the coast to $0.25 \mathrm{deg} / \mathrm{I} 00 \mathrm{~m} 87 \mathrm{~km}$ inland. It was shown by Budd ( 1966 ) that this trend of the surface gradients could be explained in terms of the heat conduction from the base with the measured ice thickness and accumulation rates and the expected motion of the ice.

The acquisition of accurate ice-movement data over the Law Dome made it practical to carry out a more detailed analysis of the temperature profiles. The model developed by Budd (1969) as an extension of the original ideas proposed by Robin (1955), accounted for the measured positive gradients on the western side of Law Dome and the negative gradients along the Casey-Vostok route. In addition negative gradients of up to $-2 \mathrm{deg} / \mathrm{I}$ oo $\mathrm{m}$ were calculated for a flow line towards Cape Poinsett (cf. Budd, I97o, and Fig. 7). On both sides of the Dome the basal temperatures were calculated to approach melting point towards the coast.

\section{Deep temperature profiles}

Deep core drilling on the Law Dome was commenced in I 969 with a thermal coring drill of a modified CRREL design constructed by Antarctic Division (cf. Bird and Ballantyne, 197I). A hole was cored to the depth of $324 \mathrm{~m}$, about $7 \mathrm{~km}$ inland from the Cape Folger coast 
where the ice thickness is about $340 \mathrm{~m}$. An open dry hole was used and severe closure and shear prevented temperature measurements below $224 \mathrm{~m}$. The measured temperature profile is shown in Figure 4, with an extrapolation to pressure melting point at the base. This extrapolation to the base involves a decrease in temperature gradient from $3.5 \mathrm{deg} / \mathrm{I}$. $2.8 \mathrm{deg} / \mathrm{r} 00 \mathrm{~m}$. Such a reduction is necessary unless an isothermal layer were to exist near the base, which would prevent the geothermal flux penetrating the ice above. As shown in Figure 4, the profile shows a measured maximum gradient equivalent to the combined heat flux of the geothermal gradient and the internal heating produced by a shear stress of about one bar and a velocity of about $10 \mathrm{~m} \mathrm{a}^{-1}$. The resultant geothermal gradient at the bed is then compatible with the base gradients inferred from the more stagnant ice above the shear moraine directly inland from Casey.

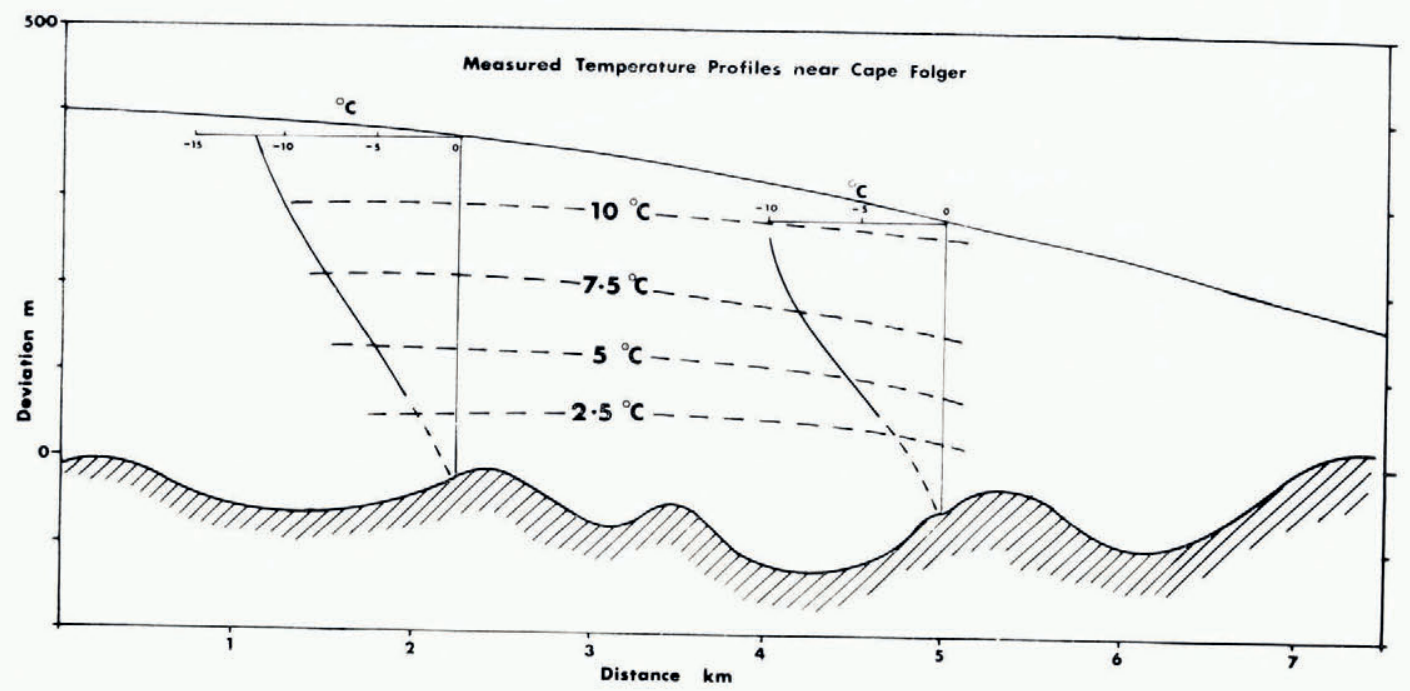

Fig. 4. The temperature profiles measured in the two Cape Folger bore holes about $3 \mathrm{~km}$ apart are shown together with isotherms in the ice. These enable horizontal temperature gradients to be obtained.

The second deep hole cored in 1969 was at the summit of Law Dome to a depth of $380 \mathrm{~m}$. In this case operational difficulties prevented temperature measurements below $320 \mathrm{~m}$. The resultant profile is shown in Figure 5. Except for a slight warming of the upper layers the profile below $200 \mathrm{~m}$ is very close to isothermal. This was expected from the high accumulation rates and increased thickness at that location as calculated by Budd (I969, fig. 4.16). The warming in the upper layer could be a result of either a few tenths of a degree climatic warming over the last century or so, or a lowering of the summit of the order of $20 \mathrm{~cm} \mathrm{a}^{-1}$ over the same period, or some combination of both of these effects. The preliminary coarsely spaced ${ }^{16} \mathrm{O} /{ }^{18} \mathrm{O}$ isotope profile given by Budd and Morgan (I973) supports such a long-term warming except in the top $20 \mathrm{~m}$ where errors due to sampling are large. An accurate analysis of this temperature and isotope data is awaiting a clear calibration of the isotope profile for the period of climatic record at Wilkes-Casey of 18 years. On the other hand a general lowering of about the above amount is suggested from both mass-balance and gravity measurements (cf. Budd, i970).

In 1972 a number of medium-depth holes $\left(5^{\mathrm{O}-1} \mathrm{I} 20 \mathrm{~m}\right)$ were cored in special strategic positions over the Dome. One was near strain grid $\mathrm{J}$, the corner of the triangle inland of Cape Poinsett, to see if the predicted highly negative gradients occurred there. Two other holes 


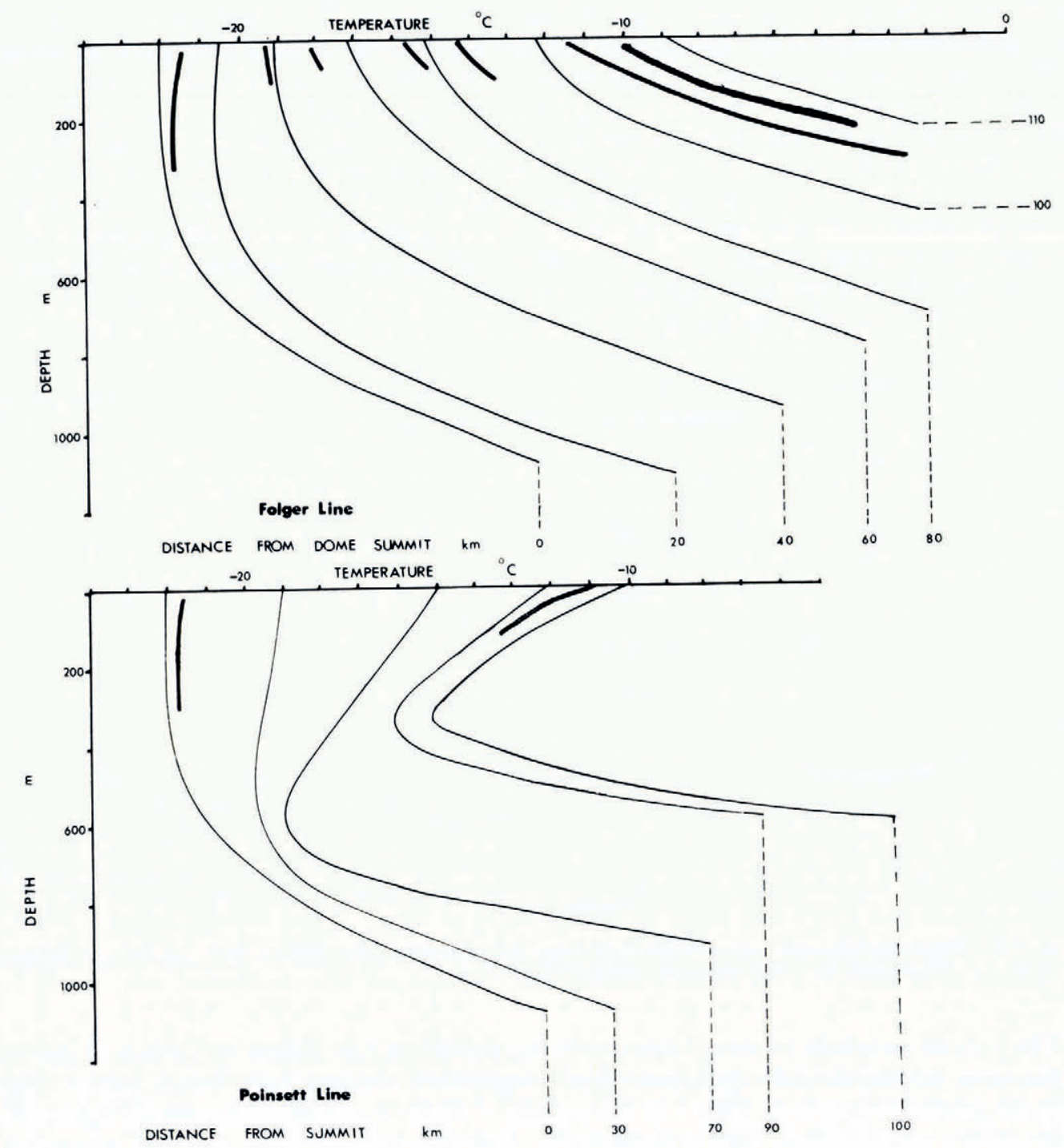

Fig. 5. The measured temperature profiles are compared with the steady-state profiles computed from the present regime along the two lines from the Law Dome summit to Cape Folger and to Cape Poinsett. The line to Cape Poinsett shows the development of the large negative temperature-depth gradients at the surface in contrast to the high positive gradients on the Folger line.

were cored at positions $\mathrm{P}$ and $\mathrm{B}$, which are about 20 and $40 \mathrm{~km}$ respectively up-stream from the hole at A. These holes were cored to obtain isotope profiles up-stream of A and also to confirm the decrease in temperature gradients inland along the flow-line as obtained from the steady-state flow-line calculations.

The measured temperature profiles are shown in Figure 5. The results clearly confirm the decrease in surface gradients going inland in a smooth systematic manner. Measurements are now available for deep surface-temperature-depth gradients at seven locations approximately along a flow line from the Dome summit to Cape Folger. These are shown in Table I and Figure 5 . 
Table I. Measured temperature-Depth Gradients

\begin{tabular}{|c|c|c|c|c|c|c|}
\hline Distance from summit $\mathrm{km}$ & o & 30 & 55 & 60 & 80 & IOO \\
\hline $\operatorname{deg} / 100 \mathrm{~m}$ & -0.1 & +0.2 & +0.4 & I.o & I. 3 & I. 8 \\
\hline
\end{tabular}

In 1974 the core drilling program was aimed at obtaining an additional core and bore hole to near the bed a few kilometres up-stream from the previous Cape Folger hole with the object of determining in addition to the temperature profile, a velocity-depth profile to check measured flow profiles of the ice core with the in situ shear rates of the ice sheet.

The program was reasonably successful. However, high closure rates and shear rates were encountered in the lower part of the hole. The ice thickness was measured as $390 \pm 10 \mathrm{~m}$ by using the radio-echo sounder. Core was obtained to the depth of $350 \mathrm{~m}$. Temperatures were measured to about $320 \mathrm{~m}$. Some inclination and inclination change measurements were also made to this depth and the bore-hole diameter logged to $317 \mathrm{~m}$. The bore hole was then filled with fluid in order to maintain the remainder of the hole open for further inclination measurements.

The bore-hole deformation and the ice-core flow and crystallographic properties will be reported elsewhere. An initial examination of the crystallography from the first hole is reported by Budd (1972).

For the moment we turn to the temperature profile shown in Figure 4. Here one of the most interesting features is the slight decrease in the gradient in the lower part of the measured profile. This is supported by the extrapolation to the bedrock at $390 \mathrm{~m}$ and pressure melting point. If the base temperature were colder than pressure melting point then the reduction in gradient would need to be even greater. As it stands the gradient decrease from $3.5 \mathrm{deg} /$ $100 \mathrm{~m}$ to $2.8 \mathrm{deg} / 100 \mathrm{~m}$ can be accounted for by the addition of internal heating. This is brought out more clearly by the modelling analysis of the temperature profiles. It is apparent from the calculations of long-term temperature changes by Budd and Young (1976) that the effects of the large Ice-Age temperature change would have penetrated well into the bedrock. Hence attention will be primarily given here to steady-state calculations.

\section{Mathematical analysis of temperature profiles}

The temperature profiles near Cape Folger have been analysed by a number of models of both the flow-line and column types described by Budd and others (197I) and Budd and Young (1976).

For example consider the column model in which $x$ is the horizontal coordinate in the line of flow, $z$ is the height above the base, $u$ and $w$ are the corresponding velocities then, for the temperature $\theta$ at time $t$,

$$
\frac{\partial}{\partial z}\left(K \frac{\partial \theta}{\partial z}\right)+\rho c w \frac{\partial \theta}{\partial z}+\rho c u \frac{\partial \theta}{\partial x}+Q_{z}=\rho c \frac{\partial \theta}{\partial t}
$$

where $K, \rho$ and $c$ are the ice conductivity, density and capacitance respectively and $Q_{z}$ is the internal frictional heating at height $z$.

The heating is given by

$$
Q_{z}=\frac{\mathrm{d} u}{\mathrm{~d} z} \rho g \alpha(z-z)
$$

where $\alpha$ is the mean surface slope, $Z$ is the ice thickness, and $g$ is the gravitational acceleration.

We assume that the flow law is given by a relation of the form

$$
\dot{\epsilon}_{0}=\dot{\epsilon}_{0}\left(\tau_{0}, \theta^{\star}, f\right)
$$

where $\dot{\epsilon}_{0}$ is the octahedral shear strain-rate and is a function of the octahedral shear stress $\tau_{0}$, 
the temperature $\theta^{\star}$ below pressure melting point $\theta_{\mathrm{m}}$, and $f$ which is a factor appropriate for the crystallographic orientation fabric of the ice. From the bore-hole and core data, $\theta^{\star}$ and $f$ can be prescribed as a function of depth.

When other stresses are negligible this then gives for the horizontal shear strain-rate

$$
\frac{\mathrm{I}}{\sqrt{ } 6} \frac{\mathrm{d} u}{\mathrm{~d} z}=\dot{\epsilon}_{0}\left(\sqrt{ } \frac{2}{3} \rho g a(Z-z), \theta^{\star}, f\right) .
$$

These equations for the velocity and temperature profile can be solved simultaneously with the following boundary conditions to give both profiles.

(a) Two temperatures $\theta_{1}$ and $\theta_{2}$ at two different levels $z_{\mathrm{I}}$ and $z_{2}$ or a temperature $\theta_{\mathrm{I}}$ at one level $z_{\mathrm{I}}$ and a temperature gradient $(\mathrm{d} \theta / \mathrm{d} z)$ at one level $z_{2}$.

(b) The horizontal velocity at the base is taken as zero.

For the vertical velocity we adopt the relation given by Budd and Young (1976)

$$
w_{z}=w_{\mathrm{s}} \frac{z}{z} \frac{\bar{u}_{z}}{V}
$$

where $\bar{u}_{z}$ is the average velocity to the height $z$ and $V$ is the average velocity through the whole column.

Thus either the average velocity or surface velocity could be provided together with a form of the flow law (containing an arbitrary factor) or the flow law could be prescribed explicitly and the velocity calculated. In most cases the velocities are known more accurately than the flow properties of the ice so that the former procedure is usually adopted.

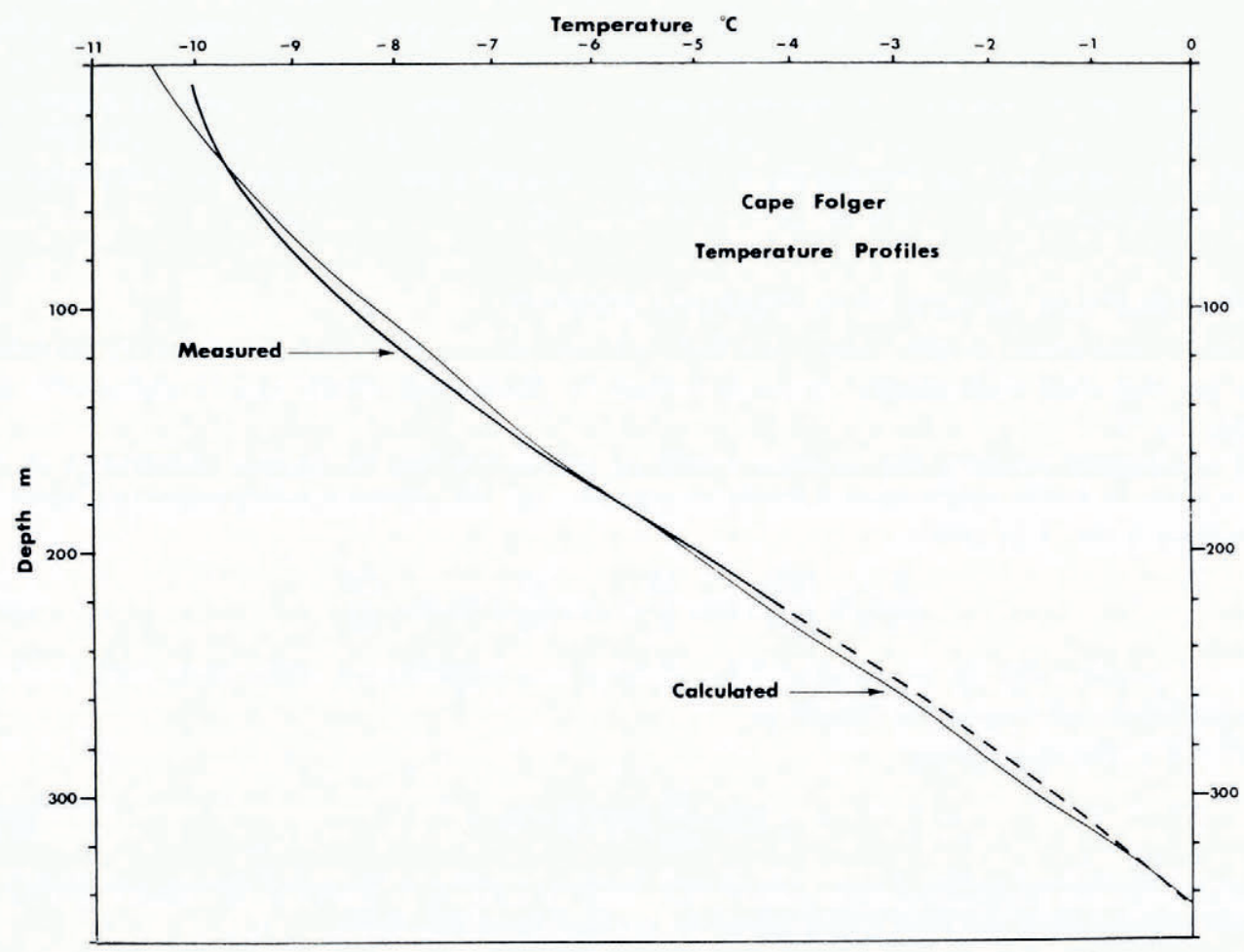

Fig. 6. For the Cape Folger bore hole the measured profile and a profile computed from the present regime are shown to agree broadly except for a slight warming of the surface and possibly greater internal heating above the base. 
A number of theoretical profiles have been scanned using different values of the vertical velocities and the horizontal temperature gradients. Closer fits can be obtained with a number of different possible combinations of these parameters but at this stage we are interested in the closeness of the approximation of this profile to steady-state under the present regime Figure 6 shows an example of a calculated profile using values of the input as close as possible to the measured values. The matching is reasonably close over most of the profile but an apparent warming of a few tenths of a degree exists at the surface. As mentioned earlier this warming is noticeable in other profiles around the dome and could be associated with either a climatic change or an elevation lowering. This effect will be treated elsewhere in conjunction with the isotope studies.

\section{Flow-Line PROFILES}

The above column model has also been used with moving coordinates along flow lines to derive a series of temperature profiles, particle paths, and ages to compare with the measured profiles. Figure 5 shows the measured and calculated temperatures along the Dome summitCape Folger line. The agreement in the surface gradients is very striking.

On the eastern side of the northern triangle the regime is remarkably different from the western side as shown in Figures I and 2. Along the Dome-Poinsett line the accumulation rates are several times higher. The bedrock is somewhat steeper towards the coast and this results in greater slopes and shear stresses. As a result the horizontal velocities are very much higher. The effect on the temperature profiles is dramatic. Instead of a trend to increasing positive gradients towards the coast the gradients towards Cape Poinsett become increasingly negative to $-2 \mathrm{deg} / \mathrm{I} 00 \mathrm{~m}$ near $\mathrm{J}$. This value agrees closely with the increased gradient there as shown in Figure 5 .

As a result the average temperature through the ice for similar elevations and surface temperatures are lower on the eastern side than the western side. This has been further confirmed by the radio-echo strengths measured by D. Carter in 1967 which were generally several decibels higher for equivalent ice thickness and surface temperature on the DomePoinsett line compared to the Dome-Folger line.

In spite of some irregularities due to the rough bedrock profiles, there is a tendency for the base temperatures along each line to approach pressure melting point towards the coast and also in deep hollows of the bedrock, as shown in Figure 7.

\section{Conclusions}

The temperature profiles measured in the Law Dome conform closely to the profiles calculated from steady-state under the present regime except for a slight warming in the firn zone near the surface of a few tenths of a degree. This warming could be caused by some combination of climatic warming during the last century or so, or slight lowering of the ice sheet.

The calculated temperature profiles from steady-state provide a sound basis for calculating the flow parameters of the ice from the measured surface velocities. These flow properties need also to be studied in association with the ice-crystal orientations.

The high bore-hole closure rates prevent much deeper drilling with the present open-hole system. It is important to obtain deeper profiles of temperature and inclination change. The development of melt-sonde probes and ice drills operating in fluid-filled holes will be required for this. 


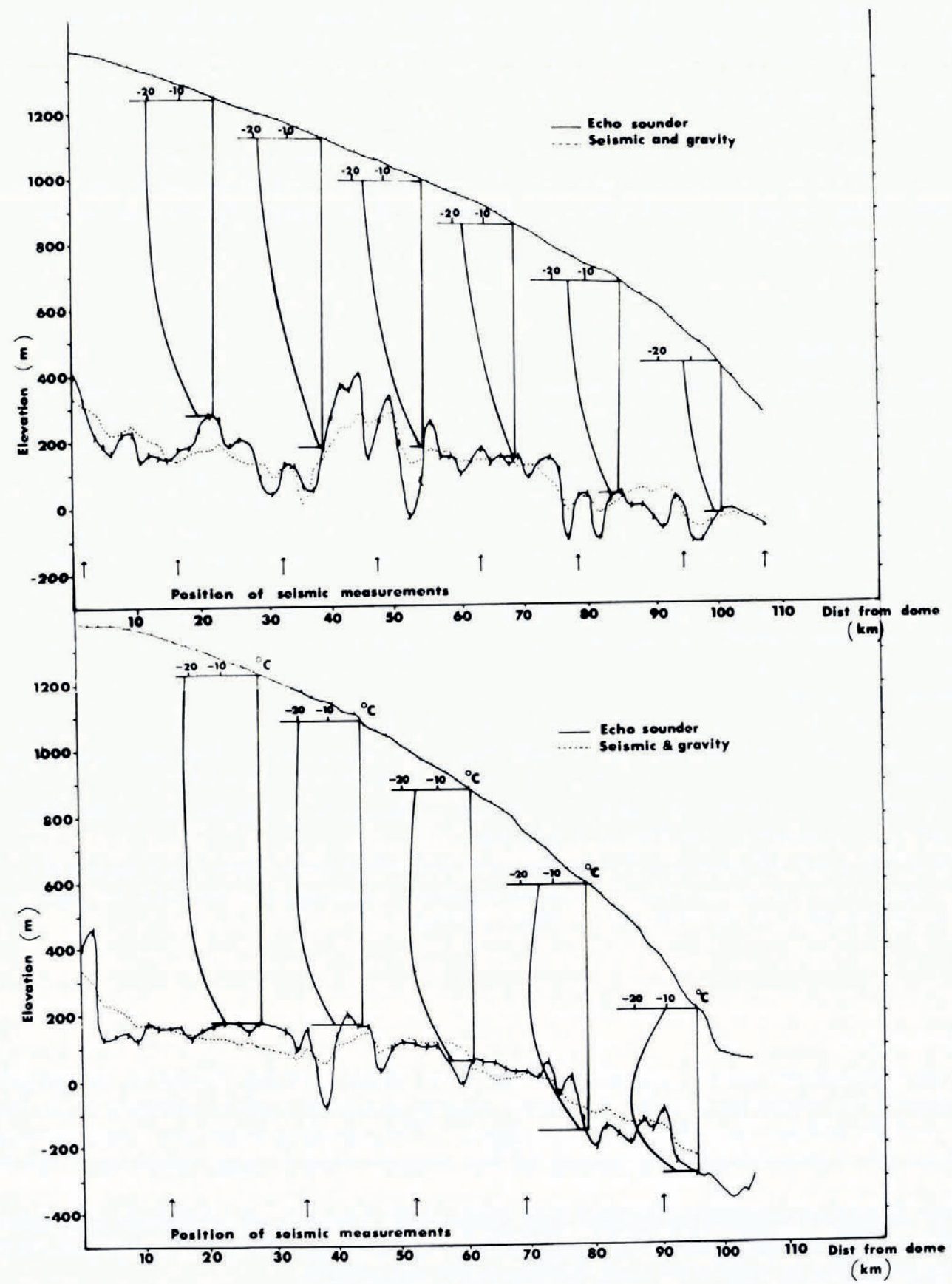

Fig. 7. The calculated temperature profiles are shown for the lines from the Law Dome summit to Cape Folger (above) and to Cape Poinsett (below) superimposed on the surface and bedrock profiles. The basal temperatures tend to approach melting point towards the coast and in the deeper bedrock hollows. 


\section{Acknowledgements}

The results presented here have been obtained over many years with support provided by Antarctic Division personnel in the field and in Australia. In particular Mr I. G. Bird has been responsible for the development of the drilling equipment and bore-hole instrumentation, Mr R. Anderson for the drilling at Casey in 1969 and Messrs D. S. Russell and K. W. Gooley for the field program of 1974 . The authors express their appreciation for the contribution of all these colleagues.

\section{REFERENCES}

Allen, G. A., and Whitworth, R. I970. Ice thickness determination at Wilkes. (In [Union Géodésique et Géophysique Internationale. Association Internationale d'Hydrologie Scientifique.] [International Council of Scientific Unions. Scientific Committee on Antarctic Research. International Association of Scientific Hydrology. Commission of Snow and Ice.] International Symposium on Antarctic Glaciological Exploration (ISAGE), Hanover, New Hampshire, U.S.A., 3-7 September 1963, p. 405-14.)

Bird, I. G., and Ballantyne, J. 1971. The design and application of a thermal ice drill. Australia. Dept. of Supply Antarctic Division. Technical Note 3.

Budd, W. F. 1966. Glaciological studies in the region of Wilkes, eastern Antarctica, 196r. ANARE Scientific Reports. Ser. A (IV). Glaciology. Publication No. 88.

Budd, W. F. 1967. Ablation from an Antarctic ice surface. (In Ōura, H., ed. Physics of snow and ice: international conference on low temperature science. ... 1966. . . . Proceedings, Vol. I, Pt. I. [Sapporo], Institute of Low Temperature Science, Hokkaido University, p. $431-46$.)

Budd, W. F. I968. The longitudinal velocity profile of large ice masses. Union de Géodésie et Géophysique Internationale. Association Internationale d'Hydrologie Scientifique. Assemblée générale de Berne, 25 sept.-7 oct. 1967. [Commission de Neiges et Glaces.] Rapports et discussions, p. 58-77.

Budd, W. F. r 969 . The dynamics of ice masses. AN $A R E$ Scientific Reports. Ser. A (IV). Glaciology. Publication No. 108.

Budd, W. F. I970. The Wilkes ice cap project. (In [Union Géodésique et Géophysique Internationale. Association Internationale d'Hydrologie Scientifique.] [International Council of Scientific Unions. Scientific Committee on Antarctic Research. International Association of Scientific Hydrology. Commission of Snow and Ice.] International Symposium on Antarctic Glaciological Exploration (ISAGE), Hanover, New Hampshire, U.S.A., 3-7 September 1968, p. 414-29.)

Budd, W. F. 1972. The development of crystal orientation fabrics in moving ice. Zeitschrift für Gletscherkunde und Glazialgeologie, Bd. 8, Ht. 1-2, p. 65-105.

Budd, W. F. I975. Antarctic sea-ice variations from satellite sensing in relation to climate. Fournal of Glaciology, Vol. 15 , No. 73 , p. 41 $7^{-27}$

Budd, W. F., and Morgan, V. I. 1973. Isotope measurements as indicators of ice flow and palaeo-climates. (In Zinderen Bakker, E. M. van, sr., ed. Palaeoecology of Africa, and of the surrounding islands and Antarctica. Vol. 8. Cape Town, A. A. Balkema, p. 5 -22.)

Budd, W. F., and Young, N. W. 1976 . Computer modelling of temperature distributions in polar ice sheets. Journal of Glaciology, Vol. i6, No. 74, p. 293-4.

Budd, W. F., and others. I971. Derived physical characteristics of the Antarctic ice sheet, by W. F. Budd, D. Jenssen and U. Radok. ANARE Interim Reports. Ser. A (IV). Glaciology. Publication No. I 20.

Cameron, R. L. I964. Glaciological studies at Wilkes station, Budd Coast, Antarctica. (In Mellor, M., ed. Antarctic snow and ice studies. Washington, D.C., American Geophysical Union, p. I-36. (Antarctic Research Series, Vol. 2.))

Cameron, R. L., and Bull, C. B. B. ${ }^{1962 .}$ The thermal diffusivity and conductivity of glacial ice at Wilkes station, Antarctica. (In Wexler, H., and others, ed. Antartic research. The Matthew Fontaine Maury memorial symposium. ... [Edited by] H. Wexler, M. F. Rubin and 7. E. Caskey, Fr. Washington, D.C., American Geophysical Union, p. 178-84. (Geophysical Monograph No. 7.))

Cameron, R. L., and others. 1959. Wilkes station glaciological data, I957-1958, by R. L. Cameron, O. Løken and J. R. T. Molholm. Ohio State University Research Foundation. Report 825-1-Pt. III.

Hollin, J. T., and others. I96r. Wilkes station glaciology, 1958, by J. T. Hollin, C. Cronk and R. Robertson. Ohio State University Research Foundation. Report $825-2-\mathrm{Pt}$. X.

Robin, G. de Q. 1955. Ice movement and temperature distribution in glaciers and ice sheets. Fournal of Glaciology, Vol. 2, No. 18, p. 523-32.

\section{DISCUSSION}

W. D. Harrison: Could the failure of the measured and calculated temperatures to match some distance above the bed be due to enhanced deformation (and hence heating) from bed irregularities? If the ice were sliding over a sinusoidal bed, for example, this distance would be about $\mathrm{I} / k$ where $k$ is the wave number. 
W. F. BudD: The difference seems to be the other way, i.e. somewhat less heat than required to increase the gradient from the base to the measured level. Thus, it seems the lower part of the ice could be less mobile than expected.

L. Lliboutry: Owing to lateral differences in ice temperatures, the direction of flow may differ from the direction of the steepest surface slope. Have you observed such an effect on the northern side of your ice cap?

BuDD: Inclination measurements made in the 1974 bore hole have been repeated over only a short interval. These suggest there may be some divergence of the flow at depth towards the west, but at this stage these results are still tentative.

M. M. Miller: Geologists versus physicists may view the concept of steady state in different time frames. Will you explain what are the parameters of your definition of a glacio-thermal steady state in terms of the boundary limits involved, the constancy or inconstancy of temperature at given levels, and lastly in terms of the other key factors affecting the regime of the total system.

BuDD : A steady-state ice cap is an abstract concept which considers a model for which all its properties, such as its temperature and velocity distributions as well as the boundary conditions, are all constant with time. This concept is useful for comparing the properties of such a model with a real ice cap in order to study how the real one may have changed with time.

T. J. Hughes: The effect of ice fabric on steady-state creep rates is quite important. You reported a three-fold increase between random and single-maximum fabrics for separate icecore specimens tested in simple shear at 0.5 bar and $-6^{\circ} \mathrm{C}$. I found an eight-fold increase when an initially random ice fabric was deformed in simple shear at 1 .o bar and $-3{ }^{\circ} \mathrm{C}$ until a strong single-maximum ice fabric developed in the same specimen. But when a similar ice specimen was tested the same way at 0.5 bar, there was no significant recrystallization after eight months and I could not be sure that transient creep still was not important.

How do you assess the effect of stress and temperature on the time needed to reach a stable ice fabric and steady-state creep? Have you been able to quantify these effects?

BuDD: The time required depends strongly on temperature. We did some recrystallization studies on core ice at $-0.2^{\circ} \mathrm{C}$ for several months; quite strong fabrics developed. But at $-2^{\circ} \mathrm{C}$, over six months, the recrystallization was very small.

J. W. GLen: What was the method of conducting a simple shear test?

BudD: We cut a I $\mathrm{cm}$ diameter core into sections of thickness small compared with the diameter. We fit plates to the top and bottom and run these plates parallel in bearings which keep the separation constant. We do see end effects in polarized light but we believe that the bulk of the sample is in simple shear.

C. F. RAYMond: Did you check whether reloading of core samples produced any structural changes in them?

BuDD: The low-temperature, low-stress test samples remaining in steady state have been examined and found to show no noticeable crystal size or fabric changes. Special recrystallization experiments however show that strong recrystallization fabrics develop after several months at $-0.2^{\circ} \mathrm{C}$ for $\mathrm{I}$ to 2 bars loading. During this time the strain-rates go beyond the initial steady state to a higher tertiary-state creep rate.

W. S. B. Paterson: Have you measured temperatures in fluid-filled holes and if so, have you any guidance as to whether they are perturbed by convection in the fluid?

BudD: No. We have only recently filled the new Folger bore hole with fluid. This will be an interesting future study there. 